\title{
Strategic Management for IT Services on Outsourcing Security Company
}

\author{
Lydia Wijaya $^{1)}$, Indra Kharisma Raharjana ${ }^{2)^{*}}$, Endah Purwanti ${ }^{3)}$ \\ 1)23) Department of Information Systems, Universitas Airlangga \\ Kampus C Mulyorejo, Surabaya, Indonesia \\ ${ }^{1)}$ lydia.wijaya-13@fst.unair.ac.id \\ 2)indra.kharisma@fst.unair.ac.id \\ ${ }^{3)}$ endah.purwanti@fst.unair.ac.id
}

\begin{tabular}{|c|c|}
\hline Article history: & Abstract \\
\hline $\begin{array}{l}\text { Received } 20 \text { February } 2018 \\
\text { Revised } 16 \text { April } 2018 \\
\text { Accepted } 18 \text { April } 2018 \\
\text { Available online } 28 \text { April } 2018 \\
\end{array}$ & $\begin{array}{l}\text { Information Technology (IT) is used by many organizations to enhance competitive } \\
\text { advantage, but many outsource security firms have not used IT in their business } \\
\text { processes. In this research, we will design Strategic Management for IT Services for }\end{array}$ \\
\hline $\begin{array}{l}\text { Keywords: } \\
\text { IT Services } \\
\text { Information Technology } \\
\text { Infrastructure Library } \\
\text { Service Strategy } \\
\text { Strategy Management }\end{array}$ & $\begin{array}{l}\text { outsourcing security company. We use an outsourcing security company as a case } \\
\text { study of IT Strategy Management for IT Services development. The purpose of this } \\
\text { study is to create an IT services strategy for security outsourcing companies. The } \\
\text { framework used is the ITIL (Information Technology Infrastructure Library) } \\
\text { framework service strategy in strategy management for IT services process. There } \\
\text { are several steps taken in the making of the strategy: (a) Strategic assessment stage } \\
\text { to analyzed internal and external factors of the company. (b) Strategy generation by } \\
\text { creating the strategic plan. (c) Strategy execution to determine the tactical plan. And } \\
\text { (d) strategy measurement and evaluation. This study produced the proposed IT } \\
\text { service system that suits the needs of the company in the form of strategic, tactical } \\
\text { plans and strategy measurement. This result can be used as the foundations of IT } \\
\text { service development in outsourcing security company. In the process of this study, } \\
\text { we work closely with stakeholders; every work product has been verified and } \\
\text { validated by stakeholders. }\end{array}$ \\
\hline
\end{tabular}

\section{INTRODUCTION}

Information Technology (IT) initially focuses only on automation, processing or data manipulation, while today IT also overcomes the function of strategic planning and services [1]. IT can become a decisive factor in organizational objectives or company if used and placed appropriately and in accordance with the needs of the business process [2]. Most companies in the field of labor supply company especially the security forces still did business process and service manual. In this technology era, the company would have problems in achieving goals, such as loss of quality in acquiring and serving clients. It became the main problem facing this company and triggered the company to use the new system. Business competition makes the quality of support services to client companies must have increased even though many challenge to be faced, both from the client side, and business side [3]. Service is providing added value to the user by providing facilities to enable users to achieve their wish [4]. To build an IT service, it is necessary to create a strategy to make the services built according to the needs and avoid the implement failure. This is because the IT service not just involves the technology alone, but involves processes that exist and the user [5]. IT is not only placed in the supporting position just like for data computing and automation of the process but is also seen as a strategic asset that determines the company's business strategy [6]. The amount of profit made by the company then leads to higher expectations about the role of IT, so IT is no longer a driving force and supports the company's strategy alone but rather as an integrated part of business strategies [7].

\footnotetext{
${ }^{*}$ Corresponding author
} 
Information Systems and Technology Services is an integrated composite that consists of a number of components, such as process management, hardware, software, facilities, and the person who provides the ability to meet the needs and objectives management [8]. One framework for IT in terms of the functions of IT services is the Information Technology Infrastructure Library (ITIL). ITIL is a framework of best practices that can be used to assist organizations in developing the Information Technology Service Management (ITSM) [9]. ITIL aims to improve the operational efficiency of IT agencies, improve service quality standards, and improve the effectiveness and efficiency of service delivery [10]. ITIL provides guidance on linking processes and activities that exist in the IT department in a structured context and was a key to quality service [1]. ITIL has domain service strategy, service design, service operation, service transition and continual service improvement. In this study focused on one of the existing processes in ITIL service strategy, strategy process management for IT services. Service Strategy provides guidance on how to look at the implementation of ITSM. ITSM concepts are used to improve organizational capability and also manage strategic company asset [11]. IT management strategy discusses the process and application of IT in the development, improvement and control IT strategy [12].

In order to realize various business objectives, the organization should use the role of IT as a supporter of the achievement of the vision and mission so that it can function as needed and in line with the goals and objectives of the organization. The purpose of this study is to optimize the utilization of systems and technology information with the goal of precise access by defining a strategy of IT services for improved information technology service management performance in the security outsourcing company. In this paper, we will define specific IT services strategies for security outsourcing companies. We use one security outsourcing company as a case study of IT services strategy creation. Based on our initial study, this company represents the characteristics of security outsourcing companies operating in Indonesia. Because we only use one company as a case study, the results of this study cannot be generalized to all companies. The use of IT services to support business processes, especially in the field of service to clients is expected to automate manual business processes, cutting out unnecessary processes, helping the efficiency of business processes, adding value to the company, providing satisfaction to customers and providing ease in the problems faced in business processes company.

\section{METHODS}

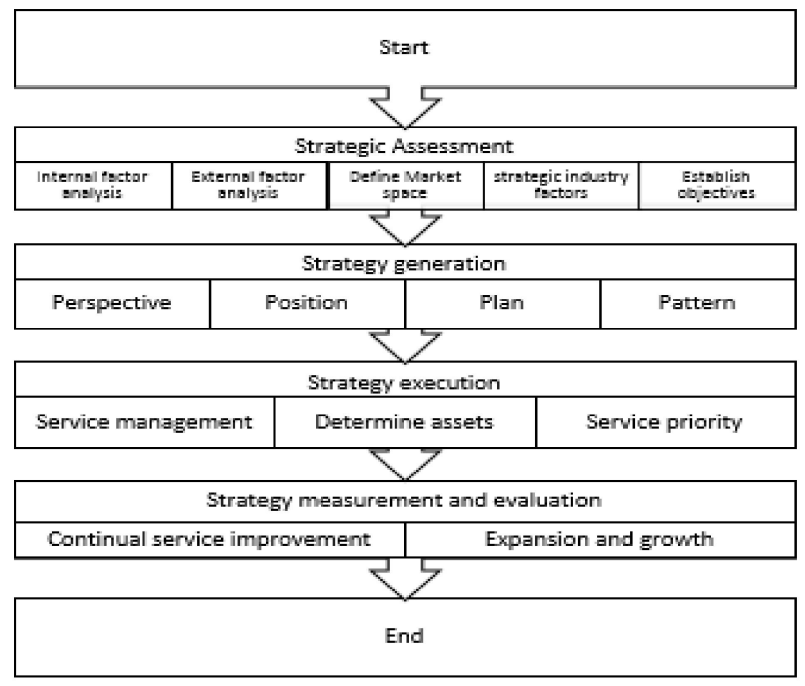

Figure 1 Research Framework

The procedures undertaken in this study adopted the steps in the ITIL Service Strategy [13] outlined in Figure 1.

\section{A. Strategic Assessment}

The strategic assessment is an initial stage in strategy management for IT services. Activities undertaken at this stage are as follows:

1) Internal and external service company analysis

Internal analysis consisted strengths and weaknesses. The external factors will be used in the analysis of opportunities and threats. The objective of this activity is to analyze whether the company needed a change of IT services to support the process of qualitative analysis services using SWOT matrix (Strength, Weakness, Opportunity, and Threat). The resulting strategy consists of four quadrants, i.e. Strength-Opportunity quadrant 
(using strength to take advantage of opportunities), Opportunity Weakness quadrant (overcoming the weaknesses by opportunity), Strength-Threat quadrant (using strength to prevent a threat), and Weakness-Threat quadrant (minimize weakness and avoid threats).

2) Market space

At this stage, identification of the scope of the enterprise market and the proposed system services in accordance with the scope of the market. This information will be used in determining the scope of the market that is used in the service strategy to be designed. This phase analyzed the data related to the enterprise market region, economic level, customers and other things that are needed in this process.

3) Strategic industry factors

This step identifies the critical factors that determine the success and failure of the service strategy; it is influenced by customer needs, business trends, competition, environmental regulations, standards, business practices to technology. The purpose of this stage is to know the needs of the organization, the reason for the service needed, the allocation of resources, and the measurement of performance in order to provide appropriate services.

4) Objectives

This activity was carried to be used as a signpost how the next stage will be run. Which should be generated in this activity is a statement of objectives to be achieved and parties involved in the use of the services and duties of such parties.

\section{B. Strategy Generation}

Documents produced at the stage of generation strategy will be used as a reference or basis during the creation service portfolio and the requirements at the stage after the service strategy that is service design, service transition, and service operation. This stage is also known as the "4 P" on service strategy, namely, Perspective, Position, Plan, and Pattern.

\section{1) Perspective}

This process determines the vision and mission that will be applied. Determined vision denotes the purpose of a service is created, while the mission is a way to achieve that vision. With a clear vision and mission will help service providers and customers in understanding things that must be done.

\section{2) Position}

The business strategy defines how a service provider can be distinguished from other service providers in the enterprise. Positions are determined based on the output of strategic assessment stage, particularly in the state of the market and the factors of corporate strategy. The position of the service provider will be demonstrated through policies on the services to be provided, and the level of customer targets, standards, and criteria used in the service, operations, and organization.

3) Plan

This stage aims to determine how to achieve the vision of the company. This step should watch strategy to be implemented, it can be used in the long term, and support all the activities of the service. This stage produces a strategic planning document.

4) Pattern

This step is done by determining the pattern of fundamental actions that will be used in decision-making and actions from time to time. In ITIL there are 4 types of patterns used: pattern of how-to, pattern boundary, the pattern priority (priority), and the pattern of the time (timing). The pattern of how-to is the framework activities to be conducted. Pattern boundary adjusts the focal point of the company, to set boundaries that can and cannot do. Priority patterns manage resource allocation and prioritize new opportunities. Timing pattern set firm action needs to be done within a certain timeframe.

\section{Strategy Execution}

Stage strategy execution explains the process that will be done in achieving the goal.

\section{1) Service Management}

Process management services enable service providers to achieve a balance between services with the desired result. Management process other services aimed provides a management system that shapes the way in regulating service providers, define services to reach opportunity was defined by the strategy, define planning to manage the service.

2) Determining Assets

In this stage adjustment of services that the assets of the service have been well coordinated and controlled so as to obtain results in accordance with the level approved. 


\section{3) Service Priority}

For each new service or project requires financing. One of the main problems faced by service providers is in investment and managerial priority on the right opportunities.

\section{Strategy Measurement and Evaluation}

Strategic and evaluation measurements aim to adopt the strategies that have been designed to be accepted and used by users.

\section{1) Continual Service Improvement}

Stages measure and evaluate the achievement of the stages of the strategy that has passed. CSI identify areas that do not run as expected, give feedback on the stage of generation and execution strategy. CSI also can be based on the manufacture of a new strategic assessment based on the results of monitoring and reporting on changes in the relevant aspects of the internal environment.

\section{2) Expansion and Growth}

In this stage, identification or development related to the possible expansion of the scope of the market use a service that has been designed in the previous stage. The expansion of the market scope may be the provision of services to new customers or the provision of new services to existing customers.

\section{RESULTS}

This chapter describes the execution of each stage of the processes in the research methodology, which can be results, timing, and attachments related to the implementation of the process.

\section{A. Strategic Assessment}

\section{1) Analysis of internal factors}

In determining the internal approach is done by identifying the strengths and weaknesses of the company. The factors used in identifying the strengths and weaknesses adjusted to the ITIL v3 framework that the current services, financial analysis, human resources, operations, relationships with business units, resources, and capabilities a day. From the observations note that the company's business relationship with the customer is going well, but the service is still manually applied to each business activity (except taxation). In regulating the performance of labor in this company is quite structured. The company has many trained work units but has a limited number of internal employees, and the resources and capabilities in technology are minimal. As for some problem faced by companies: miscommunication between business units, an error in the recording of financial statements caused by resource factors and human error, the problems related to inefficiency in action or marketing activities.

\section{2) Analysis of external factors}

In ITIL v3 external factors will be identified through the opportunities and threats by the state of the market and industry analysis, customers, partners, legislation/regulation, economic, and social, as well as technology. Based on observations, it is known that the ongoing business trend has now entered the era of the information technology. The increasing number of industry in Indonesia must also provide a good opportunity for companies to outsource service providers. The increasing number of outsourcing firms income in Indonesia from year to year, indicating that the outsourcing company increasingly sought or needed by people in Indonesia. This provides an opportunity for the company to develop the company and expand its target market. But on the other hand, more and more companies outsource growing as more and more competitors are accompanied by an increasingly competitive business environment and increase the threat of migration of customers to other parties and the decline in the number of requests to the company. The development of technology is currently one of the factors determining the success of a company. If the company is able to take advantage of technological developments it will be a very good opportunity, but otherwise, if the company cannot use it then the development of technology can be a serious threat.

\section{3) The market spaces}

For the coverage area of the company's current market is an area of East Java, especially Surabaya, Sidoarjo and surrounding areas. The target market is companies, industries, and housing that require security unit personnel (security guards). The scope of the IT services market will be expanded which can be handled the scope of a larger market area to the various provinces throughout Indonesia. Users of this service are company staff and customers of Case Study Company. The results suggested the identification of IT services can be seen in Table 1.

4) Strategic Industry Factor

Each scope of IT services that have been identified as having factors that influence the success seen from all sides, among which business trends, competition, customer requirements, standards, business practices to technology. Those factors can be seen in Table 1 . 


\section{5) Objectives}

Based on the results of internal and external analysis of the company, the strategic objectives of IT services among others providing services based on information technology and communications integrated to support business processes in the company. Providing information technology services and communications to all employees and workers ensure the availability of reliable information and communication technologies and can meet the needs of business executives.

TABLE 1

IT SERVICES IN OUTSOURCING SECURITY COMPANY

\begin{tabular}{|c|c|c|}
\hline IT Services & Service Description & Critical success factor \\
\hline Payroll system & $\begin{array}{l}\text { It is a system that serves payroll for } \\
\text { employees and labor }\end{array}$ & $\begin{array}{l}\text { 1. Accuracy in the calculation of salary, benefits, } \\
\text { etc. } \\
\text { 2. Timeliness of salary payments } \\
\text { 3. Conformity of salary given to each employee or } \\
\text { worker }\end{array}$ \\
\hline $\begin{array}{l}\text { Labor } \\
\text { Monitoring }\end{array}$ & $\begin{array}{l}\text { This service is used to assist the labor } \\
\text { monitoring process related to the division of } \\
\text { tasks, placement, and absent labor. This } \\
\text { service is used by the HR and workforce } \\
\text { sections }\end{array}$ & $\begin{array}{l}\text { 1. Truth data is absent } \\
\text { 2. Certainty hours come and go back labor } \\
\text { 3. The accuracy of information related to labor } \\
\text { turnover, overtime, absenteeism, and attendance }\end{array}$ \\
\hline $\begin{array}{l}\text { Financial } \\
\text { Statements }\end{array}$ & $\begin{array}{l}\text { This service is used by the finance } \\
\text { department in making monthly reports that } \\
\text { still use the standard spreadsheet }\end{array}$ & $\begin{array}{l}\text { 1. Accuracy of calculation of income and } \\
\text { expenditure data. } \\
\text { 2. Can show the company's financial condition } \\
\text { clearly } \\
\text { 3. Data security }\end{array}$ \\
\hline $\begin{array}{l}\text { Service } \\
\text { information and } \\
\text { customer reviews }\end{array}$ & $\begin{array}{l}\text { The service is becoming a portal for } \\
\text { information about the company to the } \\
\text { general public, this service also serves as a } \\
\text { medium that can accommodate complaints } \\
\text { and reviews from customers }\end{array}$ & $\begin{array}{l}\text { 1. Completeness of information provided in } \\
\text { accordance with customer needs } \\
\text { 2. Be able to accept customer complaints and } \\
\text { respond quickly } \\
\text { 3. Provide an overview of the company for potential } \\
\text { clients } \\
\text { 4. The interest of customers in using the services of } \\
\text { the company increases. }\end{array}$ \\
\hline $\begin{array}{l}\text { Communication } \\
\text { services }\end{array}$ & $\begin{array}{l}\text { This service is used as a medium of } \\
\text { communication between business units to } \\
\text { avoid miscommunication }\end{array}$ & $\begin{array}{l}\text { 1. Be able to convey information between business } \\
\text { units quickly. } \\
\text { 2. The accuracy of information exchange between } \\
\text { business units } \\
\text { 3. No miscommunication }\end{array}$ \\
\hline Booking service & $\begin{array}{l}\text { This service provides a service in the } \\
\text { ordering process more efficient workforce }\end{array}$ & $\begin{array}{l}\text { 1. Able to deliver orders to the company properly } \\
\text { and quickly } \\
\text { 2. Accurate calculation of cost estimates } \\
\text { 3. The existence of clarity of customer information } \\
\text { 4. Speed response to ordering }\end{array}$ \\
\hline
\end{tabular}

\section{B. Strategy Generation}

1) Perspective

In making perspective, necessary to conform to the vision of the company which $\mathrm{h}$ are consecrated in the concept of professional work will client satisfaction. The company's mission is to train noble personality \& skilled workers to carry out tasks and provide excellent service and create a safe atmosphere, comfortable quality according to standard security systems and professional. In running the business process and achieving the goals of the organization, the company aims to realize a professional service system through the development and application of information and communication technology by prioritizing client satisfaction. IT services also serve to realize the information and communication technology as a means of effective and efficient service as well as satisfying the customer, providing service system. The company is structured with skilled resources, creative, innovative, productive and dignified and expand accessibility for internal and client to information to reduce miscommunication.

2) Position

The difference the company services with other service providers is the type of services provided. The position of company service is a service provider that is needs-based positioning (services that focus on delivering services based on the needs for specific types of users, where users are serviced it is clear that internal party companies, clients and potential clients of the company). Based on the information obtained from previous analyzes, the type of 
IT service providers to be applied is the Type II IT Service Provider sharing assigned to provide a service system among company business units. Internal parties who use the service are the finance department, HRD, manager or chief executive, and marketing. As for the external parties involved were clients and prospective customers.

3) Plan

The strategy of each quadrant can be seen in Table 2. The results of the strategies that have been made from each quadrant, grouped and taken strategies that support the company's current position. The order of priority strategies to be used in support of business processes are mostly found in quadrant weakness-opportunity. To address the weaknesses found in the company by utilizing existing opportunity weakness-opportunity strategy. The weaknessthreat strategy taking into account of the existing threats in the strategy. Strength-threat quadrant will address threats by harnessing the power of the company. After preparing the human resources in the field of technology and create innovative IT services, the company can carry out the next strategy is the strategy described in the quadrant strengthopportunity to reinforce the strength of the company to take advantage of existing opportunities.

4) Pattern

In ITIL, there are 4 types of patterns used is a pattern of how-to, pattern boundary, the pattern priority, and the time pattern of timing (see Table 3 ).

TABLE 2

SWOT MATRIX

\section{Strength}

Opportunity

1) Increasing the number of industries in Indonesia.

2) Increased number of outsourcing company earnings in Indonesia from year to year.

3) The number of buildings that provide opportunities for companies to acquire new customers.

4) The high level of technology use in the current era in almost all aspects of life

\section{Threat}

1) More and more outsourced companies are growing so that more competitors are accompanied by an increasingly competitive business environment

2) The existence of the online labor market

3) The threat will be migration of customers to other parties and the decline in the number of requests to the company.

4) Regulations in Indonesia that restrict outsourcing companies into several criteria.

5) Many Indonesians still consider negative outsourcing companies

6) The changing economic condition is also one of the threat factors for business sustainability.

7) Technological developments that require companies to continue to develop innovative technologies in their business.
1) Has a lot of workforce to be employed in the field

2) Has a good performance reputation and has a good relationship and trusted by regular customers

3) Have competitive price

4) Have a workforce and skilled internal employees in their field

5) Have facilities and infrastructure for complete and in good condition

6) The working standards applied have been structured.

7) Have a normal financial condition every year.

Expanding the target market by

\section{Weakness}

1) The services applied are still done manually not yet computerized

2) The existence of human error in making monthly reports and payroll employees

3) The number of company employees is limited, resource competencies in technology are weak

4) The effectiveness and lack of efficiency in the operation due to the manual process.

5) Relationships between business units are sometimes constrained by communication that is not synchronous between sections (miscommunication).

6) Resources and capabilities in the field of technology is limited and even minimal making services based on information technology by implementing innovative IT services such as websites or online ordering systems as a medium to assist business processes and able to serve the process in a broad scope.

Improving service quality and
maintain customer loyalty by segmenting customers and giver awards to loyal customers.

Creating a web-based IT services are easily accessed either via a PC or Smartphone, attractive and understood by all users. Adding technology assets in the company

Seeking the development and training of human resources

Implement IT services capable of handling information exchange between business units to avoid miscommunication Adding human resources in IT to manage the technology assets of the company.

Increasing the promotion through advertising on the website and social media as well as services for the customer to be interested in using the security services.

Improving the quality of informative marketing activities based on technology in the form of websites and operating systems that can facilitate customers in knowing about the company and use the services of the company.

Optimizing the performance of existing human resources by utilizing information technology that supports HR performance such as financial system, marketing, recruitment, and monitoring. 


\begin{tabular}{|c|c|}
\hline Pattern & Description \\
\hline Priority & $\begin{array}{l}\text { 1. IT services should be able to process data quickly } \\
\text { 2. Availability of data when required (availability) } \\
\text { 3. Modification of service features should be complete documentation } \\
\text { 4. Preferably training that can support service development } \\
\text { 5. The handling of complaints related to services such as system hangs, error, etc. is a priority. } \\
\text { 6. Users who can access corporate internal data are only those that have access rights. }\end{array}$ \\
\hline Timing & $\begin{array}{l}\text { 1. Can be accessed anytime and anywhere } \\
\text { 2. An increase in service (upgrading) at least at each year-end. } \\
\text { 3. Information Systems customer service should not be down during the operating hours of work. } \\
\text { 4. Conduct training whenever there is a change in the service or when a new competence is required } \\
\text { 5. Documentation in the event of any changes to the system or service provided }\end{array}$ \\
\hline
\end{tabular}

TABLE 4

MANAGEMENT SERVICES

\begin{tabular}{|c|c|c|}
\hline No. & Strategy plan & Tactical plan \\
\hline 1 & $\begin{array}{l}\text { Adding technology assets } \\
\text { in the company }\end{array}$ & $\begin{array}{l}\text { a. IT services should be able to process data quickly } \\
\text { b. Using technologies that meet the standards and are always up to date, the OS used } \\
\text { minimal windows } 7 \text {. } \\
\text { c. Using the online hosting server as a data storage medium to save the company. } \\
\text { d. The use of cloud servers for backup storage place (backup's server) as an } \\
\text { alternative in the event of unexpected events and cause data loss (damage to the } \\
\text { server, natural disasters, etc.) }\end{array}$ \\
\hline 3 & $\begin{array}{l}\text { Ensuring the development } \\
\text { and training of human } \\
\text { resources }\end{array}$ & $\begin{array}{l}\text { a. Labor and employee should receive training in accordance with the field of IT } \\
\text { services } \\
\text { b. HR training has been considered and approved by superiors } \\
\text { c. Preference will be given the training to support the development of services } \\
\text { d. Training is done whenever there is a change in service or when new competencies } \\
\text { required }\end{array}$ \\
\hline 4 & $\begin{array}{l}\text { Adding human resources in } \\
\text { the field of IT to perform } \\
\text { asset management on the } \\
\text { company's technology. }\end{array}$ & $\begin{array}{l}\text { a. The number of operators in the IT services of at least } 3 \text { people. } \\
\text { b. Hiring employees who are experts in the field of IT and IT services able to operate } \\
\text { properly } \\
\text { c. IT staff assigned to perform maintenance and improvement of IT services that are } \\
\text { owned by the company } \\
\text { d. Sending a human resources representative, especially the IT staff to attend } \\
\text { seminars or training about the service }\end{array}$ \\
\hline
\end{tabular}




\section{Strategy Execution}

\section{1) Management Services:}

Things that need to be done in implementing the strategic plan that has been a priority in previous stages (manufacture plan) which is a strategy on weakness-opportunity quadrant are shown in Table 4.

2) Determining Assets

To provide targeted services, service providers must ensure that the appropriate assets and services that have been coordinated. Prior to determining the assets, it needs to be decomposition of the target users of each service will be applied. Based on the target user can then be determined assets according to its users. Some system services its proposed target of a wider community, then of the assets of the technology used must be able to access and easy to use by the general public. We can identify the assets of the technology needed by every IT services to run tactical planning that is based websites. Target customer and technology assets are provided in Table 5.

\section{3) Service Priority}

Service priority is determined based on the needs of the company and the customer. The purpose is to develop a service that can facilitate business activities and address issues facing the company and dealing with customers. Service priority is also tailored to the company's financial condition so that they can invest optimally. Approximate cost estimates for each IT service system recommend obtained from observations and discussions with IT service providers (Table 6). List of services according to the customer needs are Payment systems and payroll, Monitoring of labor, financial statements, Service information and review customers, Communication services, and Booking service.

TABLE 5

TECHNOLOGY ASSETS

\begin{tabular}{|c|c|c|c|}
\hline No & IT Services & Client target & Assets \\
\hline 1 & Payment systems and payroll & $\begin{array}{l}\text { Payments made by the client company. } \\
\text { Payroll carried out by the finance department of the } \\
\text { company. }\end{array}$ & Server, PC, wifi \\
\hline 2 & Monitoring of labor & $\begin{array}{l}\text { Monitoring conducted by the human resources } \\
\text { department of the company. } \\
\text { Attendance is done by manpower. }\end{array}$ & $\begin{array}{l}\text { Finger print device, pc or laptop, } \\
\text { wifi/router }\end{array}$ \\
\hline 3 & Financial statements & $\begin{array}{l}\text { Preparation of reports used by the finance department. } \\
\text { Checking and analysis of reports used by the chief } \\
\text { executive officer. }\end{array}$ & $\begin{array}{l}\text { PC or laptop, wifi, printer, } \\
\text { scanner }\end{array}$ \\
\hline 4 & $\begin{array}{l}\text { Service information and review } \\
\text { customers }\end{array}$ & $\begin{array}{l}\text { The information is managed by the operator. } \\
\text { Access to information and the review carried out by } \\
\text { the client or prospect }\end{array}$ & Server, PC or laptop, wifi \\
\hline 5 & Communication services & Used by all business units & PC or laptop, server \\
\hline 6 & Booking service & Used by customers or potential customers. & Server, PC, wifi \\
\hline
\end{tabular}

\section{Strategy Measurement and Evaluation}

\section{1) Continual Service Improvement}

CSI strategy identifies areas that are not in accordance with the company's expectations and could threaten the success of a strategy. CSI also monitor and report changes in the aspect of the internal environment and the ability to achieve strategic industry factors. Using the balanced scorecard (BSC) we define objects that need to be measured. Decomposition of the matter is seen in Table 6. Process measurement and evaluation strategy will be monitored by executives or directors of the company. Through the measurement rules that have explained, obtained data in the implementation of IT company services. The measurement results will be given to the chief executive as $a$ consideration material in decisions for actions to be performed in the company further. The measurement results can be used as a reference for the new strategy.

2) Expansion and Growth

Companies are required to keep innovating in business. In carrying on the business development, the company must consider market conditions that occur and take the opportunities from these market conditions. in developing the business, companies must be able to take advantage of IT as a medium for innovation and company investments. In addition, the company also needs to develop business ventures undertaken. Development may be the expansion of market scope and create a new service. Expansion efforts possible are to offer new outsourcing services to old and new customers. Services offered may include the development of the field of security, or expand the business into brand new services. Innovation services also have the potential to be developed. By looking at the growing technological era, where most people have used a Smartphone, create opportunities or potential in developing mobile applications. 


\begin{tabular}{|c|c|c|}
\hline No & Perspective & Objects \\
\hline \multirow[t]{3}{*}{1} & Finance & Increased customer satisfied thereby increasing profits (through increased revenue). \\
\hline & & Increased productivity and employee commitment to increase profit (through increased cost effectiveness) \\
\hline & & $\begin{array}{l}\text { The increase in the company's ability to generate financial returns by reducing capital employed or invest in projects } \\
\text { that generate returns high }\end{array}$ \\
\hline \multirow[t]{4}{*}{2} & Customer & $\begin{array}{l}\text { Measuring compliance to satisfy all our customer needs, maintain, acquire, and grab market share which has been } \\
\text { targeted. Benchmark in this group, namely: market share, the acquisition of the customer (customer acquisition), } \\
\text { customer retention (customers are retained), customer satisfaction, and customer profitability }\end{array}$ \\
\hline & & Attributes of services which include: functionality, price, and quality \\
\hline & & $\begin{array}{l}\text { Relationships with customers, including timely response to customer demand, as well as customers feeling after using } \\
\text { the services and the services of the company. }\end{array}$ \\
\hline & & $\begin{array}{l}\text { Image and reputation, which describes the intangible factor for companies to attract customers to get in touch with the } \\
\text { company, or use the services. }\end{array}$ \\
\hline \multirow[t]{4}{*}{3} & $\begin{array}{l}\text { Internal Business } \\
\text { Processes }\end{array}$ & $\begin{array}{l}\text { Service capabilities to meet the demands or needs without an error and timeliness in the delivery of services. The } \\
\text { measurement is divided into three principles, namely: }\end{array}$ \\
\hline & & $\begin{array}{l}\text { Process innovation: including the identification of the customer's wishes, and make the process of designing products } \\
\text { according to the customer's wishes. }\end{array}$ \\
\hline & & $\begin{array}{l}\text { Operating process: the activity of the company starting from the receipt of orders from customers. Emphasize } \\
\text { operating process to the delivery of services to customers in an efficient and timely manner. }\end{array}$ \\
\hline & & Sales service: Can be a warranty, repairs to the service error, etc \\
\hline \multirow[t]{6}{*}{4} & $\begin{array}{l}\text { Learning and } \\
\text { growth }\end{array}$ & $\begin{array}{l}\text { Employee capabilities. In connection with workers capabilities, there are three things that must be considered by the } \\
\text { management: }\end{array}$ \\
\hline & & $\begin{array}{l}\text { Employee satisfaction: Elements that can be measured is the involvement of workers in decision-making, recognition, } \\
\text { access to information, the drive to work creatively and use initiative, and support from superiors. }\end{array}$ \\
\hline & & Retention of workers: the percentage of turnover. \\
\hline & & $\begin{array}{l}\text { Worker productivity: the result of the overall effect of improving skills and morale, innovation, internal processes, and } \\
\text { customer satisfaction. }\end{array}$ \\
\hline & & $\begin{array}{l}\text { Information system capabilities. The benchmark is the level of availability of information, the accuracy of the } \\
\text { information provided, as well as the time period to obtain the information needed. }\end{array}$ \\
\hline & & $\begin{array}{l}\text { The organizational climate that encourages the emergence of motivation, and empowerment to create workers who } \\
\text { took the initiative. Benchmark that is the advice given the number of workers. }\end{array}$ \\
\hline
\end{tabular}

\section{DISCUSSION}

In this study, we use ITIL v3 strategy management for IT services to develop business service strategy. At the strategic assessment stage, the strategic factors that influence the company's service strategy has been obtained. It proceeded to the strategy generation process that produces the strategic plan. The strategy has been validated by the company and received feedback from the company. Based on the results of the feedback, the service is prioritized by the company are a website that gives services information and reviews to the customer. Services that are not prioritized are communication services between business units. Services that are not prioritized are communication services between business units because the service is already available in the employee's Smartphone service. The next stage is the strategy execution stage that produces the tactical plan. This study does not include the process of implementing IT service strategies, so there are several stages in ITIL strategy management for IT services that are not executed. In addition, the strategy execution stage that should have a comparative stage between a strategic industry factor and a critical success factor is also not executed. Related studies conducted by [14][15] also eliminate the strategy execution process. Stage of measurement and evaluation strategy produces a way of measuring the progress of the planned strategy.

In addition to ITIL, there are several other research methods that can be used to design IT strategy such as Balanced Scorecard [16], Information Engineering, Strategic Planning Information System (SPIS) Ward \& Peppard [17], Enterprises Architecture Planning with Zachman framework [18], The Open Group Architecture Framework (TOGAF) $[19,20]$. In general, ITIL service strategy is not only used to create a strategy for companies that have not applied IT, previous studies showed that ITIL service strategy used to create a strategy for agencies that have applied IT in the business activity [14, 21, 22]. Those studies explained that the organization needs a strategy in overcoming business problems associated with IT services. Although the organization has implemented IT, it still needs improvement in its implementation. many organizations cannot provide maximum IT services because they do not understand the target market, positioning, objectives and IT processing policies contained in an IT service, and do not know how to deliver such IT services [23].

In the study explained that the company or institution in question requires a strategy in addressing the business issues associated with IT services. Although the company or institution has implemented IT but still in need of an 
update and implement improvements in her milk. According [23], An agency could not provide IT services that the maximum because the service providers do not understand the target market, positioning, objectives and policy processing TI contained within an IT services and do not know how the delivery of IT services, so necessary for the manufacture of a new strategy by identifying strategic assessment and strategy generation. Identification of strategic assessment and strategy generation is required for the creation of a new strategy.

This study focuses on the problems faced by an Outsourcing Security Company in Surabaya as the case study so that strategies formulated well adapted to the needs of the organization. The study cannot be generalized for the whole company outsourcing because of differences in business processes and problems that occur in each company. Therefore, further research is needed and uses a broader case study to determine the needs of each company's outsourcing and customers in order to determine which strategy is general and flexible.

\section{CONCLUSIONS}

The right strategy for corporate use in building IT services is to increase the technology assets in the enterprise, pursue the development and training of human resources, implementing IT services that are capable of handling the exchange of information between business units to avoid miscommunication, increase human resources in the field of IT to the management of the assets of technology on the company. While the proposed IT services based on service priority order is: 1) Service and customer information; 2) The service reservations; 3) The system of payments and payroll; 4) Monitoring of labor; 5) The financial statements; 6) communication services; Target users in the execution of the system is the customer, employee, and labor internal company. Measurement strategies carried out through four perspectives: financial, customer, internal business processes, learning and growth.

In this study required a development for future research. This development is needed to update the service innovation in companies that are required to grow. The service system used is based on the website; the improvement can be done by making the innovation-based service on the mobile application. In addition, this study is recommended to proceed to further stages in accordance with ITIL v3 guidelines for the realization of the strategy that has been designed in this study into Service Portfolio Management and Financial Management.

\section{REFERENCES}

[1] A. Dipaloka, "Model Strategi IT Service," Jurnal Ilmiah Bidang Ilmu Teknologi "Tekno Insentif", p. 33, 2010.

[2] M. Bush, A. L. Lederer, X. Li, J. Palmisano and S. Rao, "The Alignment of Information Systems With Organizational Objectives and Strategies in Health Care," Information Journal of Medical Informatic, pp. 446-456, 2009.

[3] E. Infitharina, "Penerapan Information Technology Infrastructure Library Framework Pada Sistem Manajemen Service Desk (Studi Kasus: PT Tridas Widiantara)," Institut Pertanian Bogor, Indonesia, 2007.

[4] D. Cannon, ITIL Service Strategy, London: TSO, 2011.

[5] I. S. M. Forum, Foundations of IT Service Management Based on IITL V3, ITSMF International, 2007.

[6] Budiyono, E. Nugroho and W. W. Winarno, "Implementasi ITIL V3 Framework pada Penerapan Aplikasi Service Desk Management Berorientasi User," JNTETI, Vol 1, No. 2, p. 10, 2012.

[7] E. H. Apriliawan, "Self Assessment Tata Kelola Teknologi Informasi Berdasarkan Framework Information Technology Infrastructure Library (ITIL)," Universitas Pendidikan Indonesia, 2011.

[8] Evans and Macfarlane, A Dictionary of IT Service Management: Terms, Acronyms, and Abbreviations, itSMF, 2001.

[9] itSMF, An Introductory Overview of ITIL V3, United Kingdom: IT Service Management Forum Limited, 2009.

[10] L. A. K. Wardani, Murahartawaty and L. Ramadani, "Perancangan Tata Kelola Layanan Teknologi Informasi Menggunakan ITIL versi 3 Domain Service Transition dan Service Operation di Pemerintah Kota Bandung," Journal of Information System Engineering and Business Intelligence, Vol. 2, No. 2, pp. 81-87, 2016.

[11] R. Kurniawati and A. D. Manuputty, "Analisis Kualitas Layanan Teknologi Informasi dengan Menggunakan Framework Information Technology Infrastructure Library V.3 (ITIL V.3) Domain Service Transition (Studi Kasus pada Customer Service Area Telkom Salatiga)," Jurnal Teknologi Informasi-Aiti, Vol. 10. No. 1, p. 33, 2013.

[12] A. L. Poveda, Towards a Framework for Analyzing IT Strategy Management: A Case for IT Organizations in The Public Sector, Stockholm, Sweden: Royal Institute of Technology, 2011.

[13] ITIL Service Strategy, London: TSO, 2011.

[14] F. B. A. Anugroho, "Pembuatan IT Service Portfolio Berdasarkan Service Strategy ITIL V3 (Studi Kasus: Dinas Kependudukan dan Pencatatan Sipil Kabupaten Jember)," Institut Teknologi Sepuluh November, Surabaya, 2015.

[15] A. F. Putri, "Pembuatan Portofolio Layanan TI Bidang Akademik, Kemahasiswaan, Keuangan, dan Sarana Prasarana Berdasarkan Service Strategy ITIL V3 (Studi Kasus: Institut Teknologi Sepuluh November)," Institut Teknologi Sepuluh November, Surabaya, 2017.

[16] D. Aulia and A. Ikhwana, "Perencanaan Strategis Pengembangan Usaha Kain Tenun Sutra Dengan Pendekatan Metode Balanced Scorecard (Studi Kasus di Pabrik Sutra Tiga Putra)," Jurnal STT-Garut, Vol. 10 No. 01 , 2012.

[17] Ward, John and J. Pepperd, Strategic Planning for Information Systems Third Edition, Baffins Lane: John Willey \& Sons Ltd., 2002. 
Lydia Wijaya, Indra Kharisma Raharjana, \& Endah Purwanti Journal of Information Systems Engineering and Business Intelligence, 2018, 4 (1), 46-56

[18] I. Safarina, I. K. Raharjana and E. Purwanti, "Perencanaan Arsitektur Perusahaan untuk Pengelolaan Aset di PT Musdalifah Group menggunakan Kerangka Kerja Zachman," Journal of Information Systems Engineering and Business Intelligence, Vol. 1 No. 2, pp. 59-72, 2015.

[19] A. Mualo and A. D. Budiyanto, "Perencanaan Strategis Sistem Informasi Menggunakan TOGAF," Seminar Riset Teknologi Informasi (SRITI) tahun 2016, pp. 294-304, 2016.

[20] W. I. Yudhistira and E. Nugroho, "Lima Metode Perencanaan Strategis Sistem Informasi dan Teknologi Informasi untuk Pengembangan EGoverment," Seminar Nasional Teknologi Informasi dan Komunikasi 2014 (SENTIKA 2014), pp. 236-244, 2014.

[21] Y. Wirawan, A. D. Cahyono and C. Fibriani, "Perencanaan Strategi Teknologi Informasi Dengan Menggunakan Framework Information Technology Infrastructure Library (ITIL) V3 (Studi Kasus: Bagian Kerja Praktek Fakultas Teknologi Informasi)," 2014.

[22] R. P. Utami, E. Darwiyanto and I. Asror, "Audit Infrastruktur Teknologi Informasi dengan Standar Information Technology Infrastructure Library (ITIL) V.3 Domain Service Strategy dan Service Design (Studi Kasus : I-gracias)," in Indonesia Symposium on Computing, 2016.

[23] R. Hodianto, D. Sunarto and E. Sutomo, "Perencanaan Strategy Management for IT Services pada PPTI Stikom Surabaya Menggunakan Standar ITIL Versi 3," JSIKA Vol. 5, No. 9, 2016 